\title{
The morphology of the pineal gland of the Magellanic penguin (Spheniscus magellanicus Forster, 1781)
}

\author{
BARCELOS, R. P. ${ }^{1 *}$, FILADELPHO, A. L. ${ }^{2}$, BARONI, S. ${ }^{3}$ and GRAÇA, W. J. ${ }^{4}$
}

\author{
${ }^{1}$ Programa de Pós-graduação em Biologia Comparada, Universidade Estadual de Maringá - UEM, \\ Av. Colombo, 5790, Bloco G-80, Sala 201, CEP 87020-900, Maringá, PR, Brazil \\ ${ }^{2}$ Departamento de Anatomia, Instituto de Biociências, Universidade Estadual Paulista "Júlio de Mesquita Filho" - \\ UNESP, Distrito de Rubião Junior, s/n, CEP 18618-970, Botucatu, SP, Brazil \\ ${ }^{3}$ Laboratório de Genética, Colegiado de Ciências Biológicas, Universidade Federal da Fronteira Sul - UFFS, \\ Av. Jacó Reinaldo Haupenthal, 1580, CEP 97900-000, Cerro Largo, RS, Brazil \\ ${ }^{4}$ Programa de Pós-Graduação em Biologia Comparada, Departamento de Biologia, Universidade Estadual de \\ Maringá - UEM, Av. Colombo, 5790, Bloco G-80, Sala 17, CEP 87020-900, Maringá, PR, Brazil \\ *E-mail: rodrigopbarcelos@gmail.com
}

\begin{abstract}
Introduction: The Magellanic Penguin migrates on the ocean currents from its reproduction colonies in Patagonia to seek abundant food on the Brazilian continental shelf. The pineal gland, an endocrine gland, whose secretions are affected by the light-darkness photoperiod, has a basic function in the biological processes of migrating animals. Melatonin, the hormone synthesized and secreted by the pineal gland affects the circadian, circannual and seasonal cycle that directly affects the migration processes of land and sea birds. Materials and Methods: Specimens were collected on the southern coast of Brazil, morphometric assessments and histological analyses of the glands were undertaken. Results: The pineal gland of the Magellanic Penguin lies in a triangular space between the brain hemispheres and the cerebellum and close to the cavernous sinus that follow the region's dura mater. The average of the pineal gland of the penguins under analysis was $11.16 \mathrm{~mm}$ and 1,69mm for length and thickness respectively. Test $t$ and the coefficients of co-relationship (r) between the analyzed variables demonstrated that there was no co-relationship between the morphometric variables and the size of the pineal gland $(\mathrm{p}<0.05)$. The Magellanic penguin's pineal gland has a club-like sacular shape with cells in threads, involved and interlaced by fibrous conjunctive tissues. Conclusion: Results corroborated data in the literature and showed that the pineal gland of these birds is relatively greater than that of other birds and its tissue composition is similar to that of other vertebrates.
\end{abstract}

Keywords: birds, circannual cycle, migration, morphometry, pinealocytes.

\section{Introduction}

The pineal gland is an endocrine gland whose secretions are affected by the light-darkness photoperiod (GARTNER and HIATT, 2007). It has a multifunctional significance on the modulation of endocrine functions and regulation of non-endocrine systems when experiencing environmental changes or alterations of the organism (ERHART, 1992). Actually, the pineal gland is the pace-marker of the circannual infradian temporization system which monitors the seasons and synchronizes with them some functions that vary throughout the year (LENT, 2001).

Circadian rhythms are basic for the temporal organization of birds' behavior and physiology (PITTENDRIGH, 1981). Their pace-markers are complex and may be related to the several ways of life that birds experience in the different environments (GWINNER and BRANDSTÄTTER, 2001).

Circadian and circannual cycles in migratory birds are a sort of biological clock that provides the main base for their time guidance. Circannual rhythms cause the start of migration during autumn and spring. In fact, the temporization function of migrations is highly relevant for birds which migrate during the winter (GWINNER, 1996).
Magellanic penguins (Spheniscus magellanicus) are native to Argentina (south of $41^{\circ} 25^{\prime} \mathrm{S}$ ), Chili (south of $29^{\circ} \mathrm{S}$ ) and the Falkland/Malvinas Islands (approx. $51^{\circ} 45^{\prime} \mathrm{S}$ ) (WILLIAMS and BOERSMA, 1995; SCHIAVINI, YORIO, GANDINI et al., 2005). They migrate thousands of kilometers northward along the coasts of northern Argentina, Uruguay and Brazil (STOKES, BOERSMA and DAVIS, 1998; PÜTZ, INGHAM and SMITH, 2000; PÜTZ, SCHIAVINI, REY et al., 2007; FALABELLA, CAMPAGNA and CROXALL, 2009). They often arrive on the southeastern coast of Brazil $\left(22^{\circ} 17^{\prime} \mathrm{S}\right)$ and exceptionally they are reported on the Brazilian northeastern coast $\left(20^{\circ} 52^{\prime} \mathrm{S}\right)$ (SICK, 1997; GARCÍA-BORBOROGLU, BOERSMA, RUOPPOLO et al., 2010). In fact, it is the most abundant penguin species in temperate regions even though population decrease has been moderately fast during the last three generations (27 years) (BIRDLIFE INTERNATIONAL, 2014).

Since the Magellanic penguin is a migratory species, young birds and adults leave their reproductive sites after the reproduction period and displace themselves via the ocean currents in search of good feeding places (WILLIAMS and BOERSMA, 1995; FRERE, GANDINI and LICHTSCHEIN, 
1996). They follow the colder nutrient-rich waters of the Falkland current and many reach the waters of the Brazilian continental shelf (SICK, 1997; VOOREN and BRUSQUE, 1999; WEIGERT, KLIPPEL, MADUREIRA et al., 2005).

A high mortality rate of Magellanic penguins occurs on the Brazilian coast, especially in the states of Rio Grande do Sul and Santa Catarina (SICK, 1997), although very few data are extant on the number of deaths and their causes (PETRY, FONSECA and JOST, 2004). More information on the issue may be a great help for their protection (STOKES, BOERSMA and DAVIS, 1998).

More information is also required on the possible physiological basis of circannual rhythms. It is still not clear whether there are different circannual clocks that regulate migration or whether there are varied neuronal, neuroendocrinal and endocrine interactions. The situation is different when dealing with circadian rhythms. In birds the pineal organ and the supraquiasmatic nucleus in the hypothalamus cause the circadian marker.

Research tries to clarify whether the magnetic effects on birds' and mammals' melatonin synthesis either integrate a biological function tightly controlled by specific mechanisms or whether are mere artifacts of nature. It is well known that the light/darkness cycles and the earth's magnetic field have a temporal and maintenance role in higher organisms.

Although the structure of the pineal gland has been greatly investigated, Silvino (1999) reports that knowledge on the gland is based exclusively on functional observations without any reports on its morphological bases. This is due to the fact that information of the macro- and microscopic anatomy of the organ is rare and even non-existent. Knowledge on the micro- and macroscopic morphology of the pineal gland of the Magellanic penguin is important and useful for further studies since few reports are extant in the literature. Current research focuses on the macro- and microscopic analysis of the pineal gland of the Magellanic penguin.

\section{Materials and Methods}

Nine specimens were studied. They were collected in the state of Paraná, Brazil, by the Center for Sea Studies (CEM) of the Universidade Federal do Paraná (UFPR) through the Brazilian Program for the Monitoring of Magellanic Penguins. Since the specimens were already dead when collected and even in early decomposition, they were frozen and taken to the Laboratory of Animal Anatomy of the Universidade Federal do Paraná in Palotina PR Brazil, following the System for Authorization and Information in Biodiversity (SISBIO) n. 42702-1.

The birds were thawed in the laboratory, their morphometric measurements taken and fixed in formaldehyde 10\% during 20 days. Morphometric parameters for gender and the macro-and microscopic analysis of the pineal gland were further performed.

Morphometry comprised standard body measurements for differences among penguin populations, precise estimates on body conditions and growth, the species's ecology and the determination of the animals' gender. Following the Handbook for the Collection and Storage of Information and Biological Samples of Magellanic Penguins (Spheniscus magellanicus) ICMBio/MMA (BRASIL, 2012), the morphometric standards comprised length of beak (BL); height of beak (BD); length of fin-elbow (EFL); length of the posterior member (PML); width of beak (BW); width of commissure (CW); axillar circumference (AC); circumference of the head (HC); body length-head (HBL); body length-beak (BBL); total length of fin (TFL); length of tarsus (TL); length of middle finger (MTL); length of the pineal gland (CP); width of the pineal gland (LP) and weight $(\mathrm{P})$.

A digital caliper STARRET ${ }^{\circledR}, 150 \mathrm{~mm}$, resolution $0.001 \mathrm{~mm}$, was employed for morphometry. A metric tape was used for measurements above this limit.

A solution of red Neoprene Latex $450^{\circledR}$ for the visualization of the blood vessels was used for macroscopic analysis and infusion was undertaken by the common carotid artery, cranium-wise.

Encephala were accessed by an incision on the head's median line after pushing away the skin and the muscles of the temporal region.

A triangular aperture involving the frontal and parietal bones was performed in the cranial cap by a micro-rectifier DREMEL ${ }^{\circledR}$ and the opening was widened by surgical curved, fine-tipped pliers $(14 \mathrm{~cm})$.

The pineal gland was connected to the dura mater and lay between the brain hemispheres and the cerebellum. The dura mater was sectioned till its removal and separation from the hemispheres and cerebellum for the visualization of the pineal gland. After exposure, the pineal gland was removed and its length and width measured with the digital caliper.

Conventional laboratory protocol was employed for microscopic analysis. Further, $5 \mu \mathrm{m}$ thick cuts were performed with a microtome Leica ${ }^{\circledR}$ RM 2255 for the laminas, and stained with hematoxylin/eosin (HE), Masson' trichrome (TM). Laminas were analyzed under an optic microscope Leica $^{\circledR}$ DM 1000 and photodocumented by camera Leica ${ }^{\circledR}$ DFC 295 connected to the microscope. Photographs on the macroscopic aspects of the pineal gland were made by digital camera Cannon ${ }^{\circledR}$ SX30 IS.

Statistic treatment was done by the average of results from the measurements of the length of the pineal gland. The coefficients of co-relationship between the variables $\mathrm{BL}$, BD, EFL, PML, BW, CW, AC, HC, HBL, BBL, TFL, CP, LP, $\mathrm{P}$ were determined and test $t$ was applied to verify whether coefficients were different from 0 by statistical program Assistat 7.7 Beta (SILVA, 1996; SILVA and AZEVEDO, 2002, 2006, 2009). Gender was determined following Vanstreels, Adornes, Ruoppolo et al. (2011).

\section{Results}

The pineal gland of the Magellanic Penguin lies in a triangular space between the brain hemispheres and the cerebellum and close to the cavernous sinus that follow the region's dura mater. Observed during the dissection of the penguin's pineal gland, the distal section included within the dura mater and the proximal section extending of the choroid plexus (Figure la). The pineal organ of the Magellanic penguin (Sphenicus magellanicus) is rather similar to the bludgeon-shaped structure (Figure lb).

Table 1 shows the morphometric standards and measurements of the pineal gland. The pineal gland of the penguins under analysis ranged between 10.51 and $11.72 \mathrm{~mm}$ in length, average $11.16 \mathrm{~mm}$, and between 1.59 and $1.80 \mathrm{~mm}$ in thickness, average $1.69 \mathrm{~mm}$. The morphological standards showed that the penguins under analysis were young females (Table 2). The table 3 shows, at $5 \%$ level $(\mathrm{p}<0.05)$, that there was no 


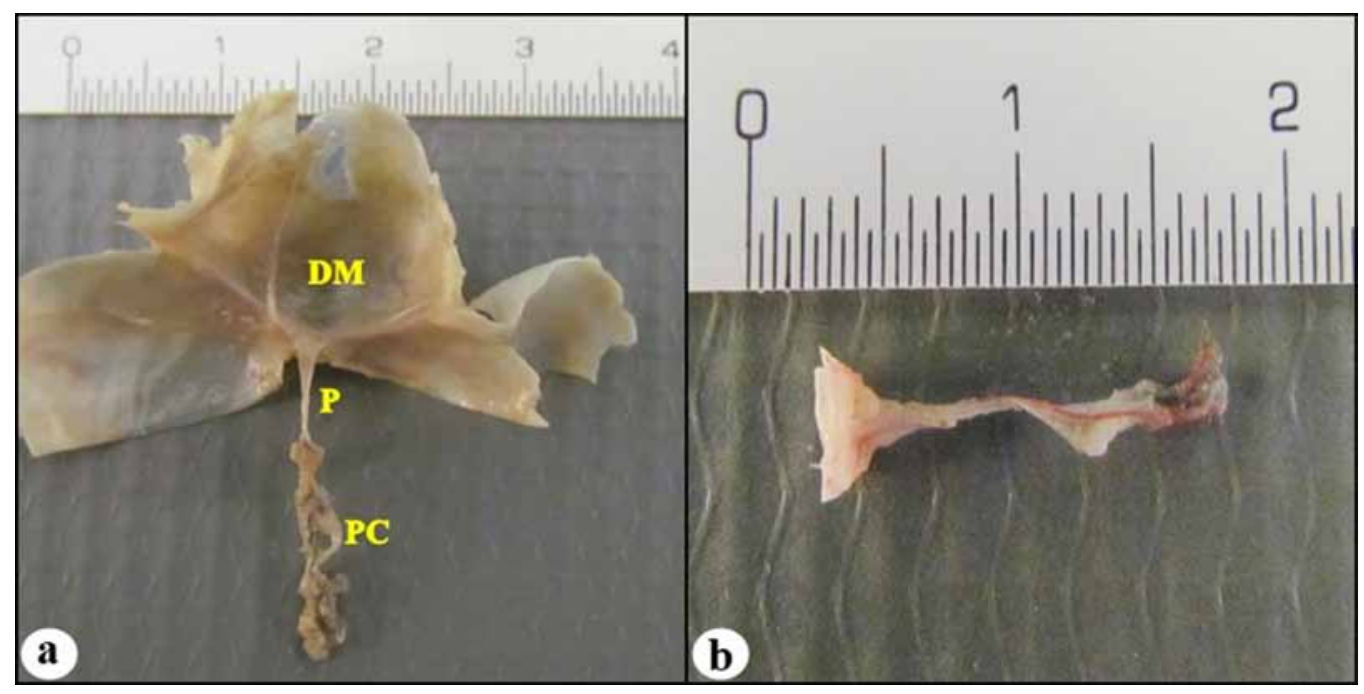

Figure 1. Pineal gland of the Magellanic penguin (Spheniscus magellanicus). (a) the distal section included within the dura mater and the proximal section extending of the choroid plexus ( $\mathrm{P}$ - pineal gland; DM - dura mater; CP - choroid plexus); (b) the pineal organ is rather similar to the bludgeon-shaped structure.

Table 1. Morphometric standards and averages of the pineal gland of the Magellanic penguin (Spheniscus magellanicus) and its respective averages (length of beak (BL); height of beak (BD); length of fin-elbow (EFL); length of the posterior member (PML); width of beak (BW); width of commissure (CW); axillar circumference (AC); circumference of the head (CH); body length-head (HBL); body length-beak (BBL); total length of fin (TFL); length of tarsus (TL); length of middle finger (MTL); length of the pineal gland $(\mathrm{CP})$; width of the pineal gland (LP) and weight $(\mathrm{P})$ ).

\begin{tabular}{|c|c|c|c|c|c|c|c|c|c|c|}
\hline & \multicolumn{9}{|c|}{ SAMPLES } & \multirow{2}{*}{ AVERAGE } \\
\hline & Pl & $\mathbf{P 2}$ & P3 & $\mathbf{P 4}$ & P5 & P6 & P7 & P8 & P9 & \\
\hline BL & 51.33 & 51.4 & 53.84 & 52.11 & $51, .8$ & 53.77 & 54.84 & 53.39 & 51.81 & 52.719 \\
\hline $\mathrm{BD}$ & 19.6 & 20.42 & 17.58 & 17.1 & 18.3 & 20.3 & 18.1 & 18.95 & 17.75 & 18.678 \\
\hline EFL & 128.27 & 128.5 & 134.13 & 130.38 & 132 & 150.07 & 136 & 143 & 122 & 133.82 \\
\hline PML & 74.34 & 83.56 & 77.13 & 78.86 & 76 & 82.02 & 79.4 & 83.45 & 80.66 & 79491 \\
\hline BW & 9.49 & 10.6 & 9.39 & 8.9 & 9.9 & 9.32 & 10.77 & 10.2 & 9.42 & 9.767 \\
\hline CW & 28.77 & 29.95 & 27.59 & 26.5 & 28.49 & 33.06 & 29.33 & 30.73 & 27.54 & 29.107 \\
\hline $\mathrm{AC}$ & 337 & 330 & 317 & 301 & 317 & 336 & 292 & 324 & 285 & 315.44 \\
\hline $\mathrm{HC}$ & 165 & 172 & 165 & 170 & 166 & 161 & 153 & 162 & 143 & 161.89 \\
\hline HBL & 478 & 482 & 524 & 485 & 458 & 593 & 481 & 481 & 442 & 491.56 \\
\hline BBL & 566 & 582 & 606 & 564 & 528 & 655 & 544 & 560 & 506 & 567.89 \\
\hline TFL & 181 & 190 & 200 & 193 & 189 & 211 & 185 & 190 & 170 & 189.89 \\
\hline TL & 45.11 & 50.79 & 51.01 & 54.67 & 48.5 & 54.4 & 48.97 & 51.62 & 49.85 & 50.547 \\
\hline MTL & 58.92 & 66.26 & 64.29 & 64.6 & 59.33 & 64.29 & 62.79 & 63.52 & 63.73 & 63.081 \\
\hline $\mathrm{CP}$ & 10.88 & 11.47 & 11.72 & 11.5 & 11.42 & 10.68 & 10.51 & 11.38 & 10.89 & 11.161 \\
\hline LP & 1.73 & 1.8 & 1.65 & 1.59 & 1.7 & 1.62 & 1.69 & 1.78 & 1.67 & 1.6922 \\
\hline $\mathbf{P}$ & 2466 & 1912 & 1720 & 1932 & 2207 & 2352 & 1950 & 2038 & 1621 & 2022 \\
\hline
\end{tabular}

Table 2. Gender of Magellanic penguins according to Vanstreels, Adornes, Ruoppolo et al. (2011).

\begin{tabular}{|c|c|c|c|c|c|c|c|c|c|}
\hline & \multicolumn{9}{|c|}{ SAMPLES } \\
\hline & Pl & P2 & P3 & P4 & P5 & P6 & P7 & P8 & P9 \\
\hline $\mathrm{BD}$ & 19.6 & 20.42 & 17.58 & 17.1 & 18.3 & 20.3 & 18.1 & 18.95 & 17.75 \\
\hline BL & 51.33 & 51.4 & 53.84 & 52.11 & 51.98 & 53.77 & 54.84 & 53.39 & 51.81 \\
\hline EFL & 128.27 & 128.5 & 134.13 & 130.38 & 132 & 150.07 & 136 & 143 & 122 \\
\hline PML & 74.34 & 83.56 & 77.13 & 78.86 & 76 & 82.02 & 79.4 & 83.45 & 80.66 \\
\hline I & -8.77 & -6.88 & -8.25 & -9.21 & -8.7 & -3.77 & -7.11 & -5.42 & -9.72 \\
\hline GENDER & q & q & o & 우 & o & o & q & q & 우 \\
\hline
\end{tabular}

$\mathrm{I}=\left(0.625^{*} \mathrm{BD}\right)+\left(0.244^{*} \mathrm{BL}\right)+\left(0.131^{*} \mathrm{EFL}\right)+\left(0.145^{*} \mathrm{PML}\right)-61.134$. If $\mathrm{I}>0$ the animal is male; if $\mathrm{I}<0$ the animal is female; if $\mathrm{I}=0$, gender cannot be determined by this technique (BD - height of beak; BL - length of beak; EFL - length of fin-elbow; PML - length of the posterior member; I - index). 
Table 3. Table of co-relationship ( $r$ ) between the variables (length of beak - BL; height of beak - BD; length of fin/elbow - EFL; length of the posterior member - PML; width of beak - BW; width of commissure - CW; axillar circumference - AC; circumference of the head - HC; body length/head - HBL; body length-beak - BBL; Total length of fin - TFL; length of tarsus - TL; length of middle finger - MTL; length of pineal gland - CP; width of the pineal gland - LP and weight - P).

\begin{tabular}{|c|c|c|c|c|}
\hline \multicolumn{3}{|c|}{ CO-RELATIONSHIP } & \multirow{2}{*}{$\begin{array}{c}\text { COEFFICIENTS OF } \\
\text { CO-RELATIONSHIP (r) } \\
12.724\end{array}$} & \multirow{2}{*}{$\begin{array}{c}\text { SIGNIFICANCE } \\
\text { ns }\end{array}$} \\
\hline $\mathrm{BL}$ & $\mathrm{x}$ & $\mathrm{CP}$ & & \\
\hline $\mathrm{BL}$ & $\mathrm{x}$ & $\mathrm{LP}$ & 13.24 & ns \\
\hline $\mathrm{BD}$ & $\mathrm{x}$ & $\mathrm{CP}$ & 26.6724 & ns \\
\hline $\mathrm{BD}$ & $\mathrm{x}$ & $\mathrm{LP}$ & 27.6724 & ns \\
\hline EFL & $\mathrm{x}$ & $\mathrm{CP}$ & 39.6724 & ns \\
\hline EFL & $\mathrm{x}$ & $\mathrm{LP}$ & 40.6724 & ns \\
\hline PML & $\mathrm{x}$ & $\mathrm{CP}$ & 51.6724 & ns \\
\hline PML & $\mathrm{x}$ & $\mathrm{LP}$ & 52.6724 & ns \\
\hline BW & $\mathrm{x}$ & $\mathrm{CP}$ & 62.6724 & ns \\
\hline BW & $\mathrm{x}$ & $\mathrm{LP}$ & 63.6724 & * \\
\hline $\mathrm{CW}$ & $\mathrm{x}$ & $\mathrm{CP}$ & 72.6724 & ns \\
\hline $\mathrm{CW}$ & $\mathrm{x}$ & $\mathrm{LP}$ & 73.6724 & ns \\
\hline $\mathrm{AC}$ & $\mathrm{x}$ & $\mathrm{CP}$ & 81.6724 & ns \\
\hline $\mathrm{AC}$ & $\mathrm{x}$ & $\mathrm{LP}$ & 82.6724 & ns \\
\hline $\mathrm{HC}$ & $\mathrm{x}$ & $\mathrm{CP}$ & 89.6724 & ns \\
\hline $\mathrm{HC}$ & $\mathrm{x}$ & $\mathrm{LP}$ & 90.6724 & ns \\
\hline $\mathrm{HBL}$ & $\mathrm{x}$ & $\mathrm{CP}$ & 96.6724 & $\mathrm{~ns}$ \\
\hline $\mathrm{HBL}$ & $\mathrm{x}$ & $\mathrm{LP}$ & 97,6724 & ns \\
\hline $\mathrm{BBL}$ & $\mathrm{x}$ & $\mathrm{CP}$ & 102.6724 & ns \\
\hline BBL & $\mathrm{x}$ & $\mathrm{LP}$ & 103.6724 & ns \\
\hline TFL & $\mathrm{x}$ & $\mathrm{CP}$ & 107.6724 & ns \\
\hline TFL & $\mathrm{x}$ & $\mathrm{LP}$ & 108.6724 & ns \\
\hline TL & $\mathrm{x}$ & $\mathrm{CP}$ & 111.6724 & ns \\
\hline TL & $\mathrm{x}$ & $\mathrm{LP}$ & 112.6724 & ns \\
\hline MTL & $\mathrm{x}$ & $\mathrm{CP}$ & 114.6724 & ns \\
\hline MTL & $\mathrm{x}$ & $\mathrm{LP}$ & 115.6724 & ns \\
\hline $\mathrm{P}$ & $\mathrm{x}$ & $\mathrm{CP}$ & 116.6724 & ns \\
\hline $\mathrm{P}$ & $\mathrm{x}$ & $\mathrm{LP}$ & 117.6724 & ns \\
\hline $\mathrm{CP}$ & $\mathrm{x}$ & $\mathrm{LP}$ & 118.6724 & ns \\
\hline
\end{tabular}

* Significant at $5 \%$ probability $(0.01=<\mathrm{p}<0.05)$. ns - not significant $(\mathrm{p}>=0.05)$. Teste $t$ at 5 and $1 \%$.

co-relationship between the morphometric variables and the size of the pineal gland, except for the BW and LP.

The Magellanic penguin's pineal gland has a club-like sacular shape (Figure 2a). An arterial vessel runs throughout the extension of the gland connected to the conjunctive tissue that involves it (Figure 2b), the constitution of the collagen fibers that compose the conjunctive tissue of the dura mater may be seen with Masson's trichrome stain. Abundant conjunctive fibrous tissue with several fibroblasts, fibrocytes and cells of the immune tissue may be observed (Figure $2 \mathrm{c}, \mathrm{d}$ ).

\section{Discussion}

The location of the pineal gland of the Magellanic Penguin in a triangular space between the brain hemispheres and the cerebellum and close to the cavernous sinus that follow the region's dura mater, as described by Redins and Machado (1989) for Crypturellus parvirostris. Its distal section is partially included within the dura mater conjunctive (REDINS and MACHADO, 1984).
According to Pal, Ghosal, Minj et al. (2013), birds' pineal gland lies on the surface within the triangular space posterior to the junction of the brain hemispheres and the cranial section of the cerebellum. A long shaft connects the pineal bland to the roof of the third ventricle by means of the choroid plexus (PRUSIK, LEWCZUK, NOWICKI et al., 2006; PAL, GHOSAL, MINJ et al., 2013). According to Gladstone and Wakeley (1940), birds' pineal gland is a rather long tube connected to the cavity of the third ventricle, due to the big size of the hemispheres and cerebellum.

Gallardo and Piezzi (1973) report that, similar to other birds, the pineal gland of the long-tailed gentoo penguin (Pygoscelis papua) is a solid parenquimatous long structure surrounded by a capsule of conjunctive tissue and meninges. It extends cranially between the brain and the cerebellum as a continuation of the choroid plexus.

Due to the great variability of its anatomic, histological, organization, innervation and ultrastructure, the pineal gland varies in size and shape more than any other part of birds' brain (OHSHIMA and HIRAMATSU, 1993; HALDAR and 




Figure 2. Cross-section of the pineal gland of the Magellanic penguin (Spheniscus magellanicus). (a) pinealocytes arranged in threads - HE staining - 200X; (b) arterial vessel and blood vessels (VS), with blood cells - HE staining - 200X; (c) conjunctive tissue (TC) and pinealocytes (P) and blood vessels (VS); TM staining - 200X; (d) cell threads of pinealocytes (P) with euchromatic and rounded nuclei, Glia cells $(\mathrm{G})$ with dense and smaller nuclei, conjunctive tissue with fibroblasts (F), fibrocytes (FC) and melanin pigment (M) - HE staining - 1000X.

GUCHHAIT, 2000; FEJER, ROHLICH, SZEL et al., 2001; HALDAR and BISHNUPURI, 2001). Haldar and Guchhait (2000) studied the owl species Athene brama and reported that the pineal gland is a triangle-shaped structure funneling towards a cylindrical shaft that extends to the habenular commissure, sub-commissure organ and choroid plexus.

In their studies on the sparrow (Passer montanus), Singh and Dixit (2014) described the pineal gland as a long brain epiphysis with a long tube which ends in a widened tissue structure called choroid plexus. Redins and Machado (1989) report that birds' pineal gland may be classified into three organizational standard types, or rather, sacular pineal, tubulefollicular pineal and solid pineal types. The pineal gland in the small-billed tinamou (Crypturellus parvirostris) has the form of a bludgeon, with a tapering section that gradually thickens up to the distal section. It has a follicular organization and related to the other epithalamium formations. The pineal organ of the Magellanic penguin (Sphenicus magellanicus) is rather similar to the bludgeon-shaped structure of the Crypturellus parvirostris and other Tinamiform birds such as Crypturellus somi (little tinamou) and Tinamus solitarius(solitary tinamou), as described by Redins and Machado (1984, 1989); Redins and Novaes (1990).

The measurements of the average of the pineal gland under analysis was $11.16 \mathrm{~mm}$ and $1.69 \mathrm{~mm}$ for length and thickness respectively, whereas the hen's pineal gland is $2.5 \mathrm{~mm}$ long and $1.5 \mathrm{~mm}$ thick (GETTY, 1986). From the macroscopic point of view and with the due relative body proportions, the pineal gland of the Magellanic penguins is longer and practically has the same thickness as that of domestic fowls.

Redins and Novaes (1990) reported that there were morphological differences in the pineal glands of birds during the reproduction period when compared to those which were reproductively quiescent. These data may indicate a possible involvement of the organ in the mechanism of bird reproduction.

The morphological standards showed that the penguins under analysis were young females and in the non-reproductive 
period. Morphological differences may occur in the pineal glands of adult penguins during the reproductive period.

Penguins' gender results showed the preponderance of females and corroborate studies by Vanstreels, Adornes, Canabarro et al. (2013) that most of the 528 sampled specimens between 2002 and 2009 were females.

Test $t$ and the coefficients of co-relationship (r) between the analyzed variables demonstrated that there was no co-relationship between the morphometric variables and the size of the pineal gland, except for the width of the beak (BW) and the width of the pineal gland (LP). Although the test revealed correlation, no physiological evidence exists between the functioning of the pineal gland and the width of the bird's beak.

The Magellanic penguin's pineal gland has a club-like sacular shape with cells in threads, involved and interlaced by fibrous conjunctive tissues. The cellular thread in the distal section is made up of pinealocytes and is more swelled and connected to the tissue that composes the dura mater. Its proximal section is thinner and is positioned close to the choroid plexus.

Small blood vessels occur throughout the cellular thread, interlaced in the conjunctive tissue (Figure 2c) and arterioles, common in endocrine glands, which reach the gland and allow the fast transport of melatonin.

The parenchyma of the pineal gland is rich in pinealocytes, or rather, modified neurons with endocrine functions. These cells have euchromatic rounded nuclei and nucleoli. The cytoplasms are slightly stained and abundant in some sections (Figure $2 \mathrm{~d}$ ). Smaller long-shaped nuclei, heterochromatic (strongly stained), corresponding to Glia cells, probably astrocytes, may be seen interlaced to the parenchyma of the gland (rich in pinealocytes) (Figure 2d). HE-stained laminas show melanophores, cells which produce melanin present in the organs connected with light sources (Figure $2 \mathrm{~d}$ ). The laminas failed to show any calcium concretions (acervuli cerebri) perhaps due to the young age of the penguins under analysis. The above data is highly relevant since concretions are important for the determination of the earth's magnetic field by birds. Further histological studies on the pineal gland of adult penguins are important to confirm the presence of concretions.

The human pineal gland is externally coated by the pia mater from which septa of conjunctive tissues derive and which penetrate the gland, dividing it into lobules. These septa forward vessels and nerves into the gland (JUNQUEIRA and CARNEIRO, 2013). According to Venzke (1986), several species of animals have trabecules of aerolar thin conjunctive tissue that divide the organ into lobules. Cuts in the pineal gland of the Magellanic penguin showed that the dura mater is a tissue that envelope the gland, from which tissues are derived. They penetrate the gland's parenchyma but do not separate it into lobules. Under an optic microscope, these histological data suggest that the gland is made up of cellular threads.

In their research on capybaras, Branco, Guimarães, Miglino et al. (1997) demonstrated histological data very similar to current analysis. The authors reported that pinealocytes are polyhedron cells with abundant cytoplasm, rounded nuclei, arranged in threads that give a homogeneous aspect to the gland. The pinealocytes registered by the above authors are arranged in threads interlaced with conjunctive tissue and glial cells.

Silvino, Miglino, Didio et al. (1995) reported that the pinealocytes of the agouti (Dasyprocta aguti) are arranged in a thread-like manner and give a homogeneous and solid aspect to the gland.

Pinealocytes and glial cells were found in the pineal gland of buffaloes (Bubalus buballis) by Carvalho, Ambrósio, Miglino et al. (2009), capuchin monkeys (Cebus apela) by Carvalho-Barros (2006) and in the adult cat by Boya, Calvo and Rancano (1995). In their studies on the crab-eating raccoon (Procyon cancrivorus), Marques, Carvalho, Maçanares et al. (2010) registered that pinealocytes are distributed in threads, similar to current data on Magellanic penguins.

Singh and Dixit (2014) observed that the pineal gland of sparrows (Passer montanus) is structured by a follicular tissue with two different types of cells: pinealocytes and glial cells, which are smaller and arranged along the secular-shaped gland with a small lumen.

Glial cells are always registered in the histology of mammals, birds and reptiles, and show that gland receives neuro-sensorial or photo-receptive signalization. Since pinealocytes synthesize melatonin, nerve terminations are closer to the blood vessels than to cells. Consequently, neurotransmitters are released at the perivascular spaces and then they are disseminated to the surface of the pinealocytes (MOORE, 1996; VOLLRATH, $1985)$.

Holanda-Barros (2002) observed that snakes' pineal gland is structured on acini with dark cells, rounded nucleus, between spherical and oval, with loose chromatin and nucleoli. Cells with chestnut-like granules that suggest melanocytes in the region are also extant. Redins and Machado (1989) report that melanocytes and pigments exist in the several genera of Tinamiforms. A reasonable amount of melanin is evident in the pineal of the Magellanic penguin but the individual cells could not be seen. The pigment in the pineal tissue suggests that light has an important role in the regulation of the birds' gland.

Machado (1965) reports that the histology of the pineal tissue in Didelphis sp. is characterized by an abundance of modified glial fibers and ependimary cells, whereas pinealocytes and glial cells, in smaller amounts, predominate in the gland tissue of the penguins analyzed.

The literature which includes the histological study of the pineal gland indicates Redins' research as a reference in birds. His study on Tinamiform birds elucidates the histological composition of the group's pineal gland. Redins and Machado (1989) investigated the structure of the pineal gland of three genera of this order and showed that the birds' pinealocytes are organized as genus-dependent big to small follicles. Their results reveal a lymphoid tissue immediately below the dura mater which couldn't be observed in current analysis. The lymphoid tissue in the birds' pineal gland was also mentioned by Quay (1965) for other bird species and its histogenesis was particularly researched in hens (SPIROFF, 1958; BOYA and CALVO, 1978).

\section{Conclusion}

Current research revealed the following valid conclusions:

The pineal gland of the Magellanic penguin lies in the space between the brain hemispheres and the cerebellum, close to the cavernous sinus that accompany the dura mater. It is shaped like a bludgeon and extends between the choroid plexus and the dura mater.

The histological aspects foreground tissue and cell similarities with the pineal gland of other vertebrates. The physiological 
and genetic regulation determines in which aspects the gland affects the behavior of the birds. The pinealocytes and glial cells suggest that melatonin is secreted through a nervous signal, probably by external light which regulates the circadian and circannual cycles underlying the migration of the species. The lack of calcium concretions is a highly relevant datum and requires further studies on the pineal gland of adult specimens.

\section{References}

BIRDLIFE INTERNATIONAL. Species factsheet: Spheniscus magellanicus. Cambridge, 2014. Available from: <http://www. birdlife.org/datazone/speciesfactsheet.php?id=3863>. Access in: 01 Aug. 2014.

BOYA, J. and CALVO, J. Post-hatching evolution of the pineal gland of the chicken. Acta Anatomica, 1978, vol. 101, n. 1, p. 1-9. http:// dx.doi.org/10.1159/000144943. PMid:645330.

BOYA, J., CALVO, JL. and RANCANO, D. Structure of the pineal gland in the adult cat. Journal of Pineal Research, 1995, vol. 18, n. 2, p. 112-118. http://dx.doi.org/10.1111/j.1600-079X.1995. tb00148.x. PMid:7629690.

BRANCO, ER., GUIMARÃES, A., MIGLINO, MA., DIDIO, LJA., NURMBERGER, R. and SOUZA, WM. Pesquisa anatômica da glândula pineal em capivaras (Hydrochoerus hydrochoeris). Brazilian Journal of Veterinary Research and Animal Science, 1997, vol. 34, n. 4, p. 191-195.

BRASIL. Ministério do Meio Ambiente. Instituto Chico Mendes de Conservação da Biodiversidade. Manual de campo para a colheita e armazenamento de informações e amostras biológicas provenientes de pinguins-de-magalhães (Spheniscus magellanicus). Brasília: MMA, 2012. 62 p.

CARVALHO, AF., AMBRÓSIO, CE., MIGLINO, MA., MANÇANARES, CAF. and BLAZQUEZ, FJH. Macro-microscopical aspects of the buffalo (Bubalus bubalis Linnaeus, 1758) pineal gland. Biotemas, 2009, vol. 22, n. 2, p. 127-135.

CARVALHO-BARROS, RA. Anatomia macro e microscópica da glândula pineal de (Cebus apella). São Paulo: Universidade de São Paulo, 2006. 165 p. [Tese de Doutorado em Anatomia dos Animais Domésticos e Silvestres].

ERHART, EA. Elementos de Anatomia Humana. 8th ed. São Paulo: Atheneu, 1992. $272 \mathrm{p}$.

FAlABElla, V., CAMPAGNA, C. and CROXALl, J. Atlas of the Patagonian Sea. Species and Spaces. Buenos Aires: Wildlife Conservation Society and Birdlife International, 2009. 303 p.

FEJER, Z., ROHLICH, P., SZEL, A., DAVID, C., ZADORI, A., MANZANO, MJ. and VIGH, B. Comparative Ultrastructure and cytochemistry of the avian pineal organ. Microscopy Research and Technique, 2001, vol. 53, n. 1, p. 12-24. http://dx.doi.org/10.1002/ jemt.1064. PMid:11279666.

FRERE, E., GANDINI, P. and LICHTSCHEIN, V. Variación latitudinal em la dieta del pingüino de Magallanes (Spheniscus magellanicus) em la costa Patagónica, Argentina. Ornitología Neotropica, 1996, vol. 7, p. 35-41.

GALLARDO, MP. and PIEZZI, RS. Serotonin content in the pineal gland of the antartic penguin (Pygoscelis papua). General and Comparative Endocrinology, 1973, vol. 21, n. 3, p. 468-471. http:// dx.doi.org/10.1016/0016-6480(73)90106-8. PMid:4762863.

GARCÍA-BORBOROGLU, P., BOERSMA, PD., RUOPPOLO, V., PINHO-DA-SILVA-FILHO, RP., CORRADO-ADORNES, A., CONTE-SENA, D., VELOZO, R., MYIAJI-KOLESNIKOVAS, C., DUTRA, G., MARACINI, P., CARVALHO-DO-NASCIMENTO, C., RAMOS-JÚNIOR, V., BARBOSA, L. and SERRA, S. Magellanic penguin mortality in 2008 along the SW Atlantic coast. Marine Pollution Bulletin, 2010, vol. 60, n. 10, p. 1652-1657. http:// dx.doi.org/10.1016/j.marpolbul.2010.07.006. PMid:20674946.

GARTNER, LP. and HIATT, JL. Tratado de histologia em cores. 3rd ed. Rio de Janeiro: Elsevier, 2007. 592 p.

GETTY, R. Anatomia dos animais domésticos. 5 th ed. Rio de Janeiro: Guanabara Koogan, 1986. 2 vols., 2048 p.

GLADSTONE, RJ. and WAKELEY, CPG. The pineal organ. London: Williams and Wilkins Co., 1940. 528 p.

GWINNER, E. and BRANDSTÄTTER, R. Complex bird clocks. Philosophical Transactions of the Royal Society of London. Series B, Biological Sciences, 2001, vol. 356, n. 1415, p. 1801-1810. http:// dx.doi.org/10.1098/rstb.2001.0959. PMid:11710987.

GWINNER, E. Circadian and circannual programmes in avian migration. The Journal of Experimental Biology, 1996, vol. 199, n. 1, p. 39-48. PMid:9317295.

HALDAR, C. and BISHNUPURI, KS. Comparative view of pineal gland morphology of nocturnal and diurnal birds of tropical origin. Microscopy Research and Technique, 2001, vol. 53, n. 1, p. 25-32. http://dx.doi.org/10.1002/jemt.1065. PMid:11279667.

HALDAR, C. and GUCHHAIT, P. Pineal gland of a nocturnal bird, Indian spotted owlet, Athene brama: morphological and endocrine observations. The Journal of Experimental Zoology, 2000, vol. 287, n. 2, p. 145-150. http://dx.doi.org/10.1002/1097010X(20000701)287:2<145::AID-JEZ4>3.0.CO;2-K. PMid:10900433.

HOLANDA-BARROS, PM. Estudo da pineal em jararacas (B. jararaca) e cascavéis (C. durissus). São Paulo: Universidade de São Paulo, 2002. 82 p. [Dissertação de Mestrado em Anatomia dos Animais Domésticos e Silvestres].

JUNQUEIRA, LC. and CARNEIRO, J. Histologia básica. 12th ed. Rio de Janeiro: Guanabara Koogan, 2013. 556 p.

LENT, R. Cem Bilhões de neurônios: conceitos fundamentais de neurociência. São Paulo: Atheneu, 2001. 765 p.

MACHADO, ABM. Dados histológicos e embriológicos sobre a região pineal em alguns marsupiais brasileiros. Ciencia e Cultura, 1965, vol. 17, n. 2, p. 249.

MARQUES, OL., CARVALHO, AF., MANÇANARES, ACF. and MANÇANARES, CAF. Estudo morfológico da glândula pineal de Procyon cancrivorus (Cuvier, 1798) (mão-pelada). Revista Biotemas, 2010, vol. 23, n. 2, p. 163-171.

MOORE, R. Neural controlo f pineal gland. Behavioural Brain Research, 1996, vol. 73, n. 1-2, p. 125-130. PMid:8788489.

OHSHIMA, K. and HIRAMATSU, K. Ultrastructural study of posthatching development of the pineal gland in the Japanese quail. The Journal of Veterinary Medical Science, 1993, vol. 55, n. 6, p. 945-950. http://dx.doi.org/10.1292/jvms.55.945. PMid:8117821.

PAL, B., GHOSAL, AK., MINJ, AP. and GHOSH, RK. Comparative histomorphological study of the pineal gland in human and fowl. The American Journal of the Medical Sciences, 2013, vol. 6, n. 1, p. 80-84. PMid:23360793.

PETRY, MV., FONSECA, VS. and JOST, AH. Registro de Pinguinsde-magalhães (Spheniscus magellanicus) mortos no Rio Grande do Sul. Acta Biologica Leopoldinense, 2004, vol. 26, n. 1, p. 139-144.

PITTENDRIGH, CS. Circadian systems: entrainment. In: ASCHOFF, J. (Org.). Handbook of behavioral neurobiology, biological rhythms. 4th ed. New York: Plenum Press, 1981. p. 57-80.

PRUSIK, M., LEWCZUK, B., NOWICKI, M. and PRZYBYLSKAGORNOWICZ, B. Histology and ultrastructure of the pineal organ in the domestic goose. Histology and Histopathology, 2006, vol. 21, n. 10, p. 1075-1090. PMid:16835830. 
PÜTZ, K., INGHAM, RJ. and SMITH, JG. Satellite tracking of the winter migration of Magellanic Penguins Spheniscus magellanicus breeding in the Falkland Islands. The Ibis, 2000, vol. 142, n. 4, p. 614-622. http://dx.doi.org/10.1111/j.1474-919X.2000.tb04461.x.

PÜTZ, K., SCHIAVINI, A., REY, AR. and LÜTHI, BH. Winter migration of magellanic penguins (Spheniscus magellanicus) from the southernmost distributional range. Marine Biology, 2007, vol. 152, n. 2, p. 1227-1235. http://dx.doi.org/10.1007/s00227-007-0770-5.

QUAY, WB. Histological structure and cytology of the pineal organ in birds and mammals. Progress in Brain Research, 1965, vol. 10, p. 49-86. http://dx.doi.org/10.1016/S0079-6123(08)63447-0. PMid:14281620.

REDINS, CA. and MACHADO, ABM. Histologic study of the pineal organ in tinamid birds. Revista Brasileira de Biologia, 1989, vol. 49, n. 2, p. 429-434. PMid:2608946.

REDINS, CA. and MACHADO, ABM. Ultra-estrutura do órgão pineal do Crypturellus parvirostris Wagler, 1897 (Aves. Tinamiformes). Revista Brasileira de Biologia, 1984, vol. 44, n. 4, p. 499-508. PMid:6537598.

REDINS, CA. and NOVAES, JC. Estudo morfométrico do órgão pineal de Crypturellus parvirostris (Aves: Tinamiformes) em diferentes fases do ciclo sexual. Revista brasileira de Ciências Morfológicas, 1990, v.7, n. 1.

SCHIAVINI, A., YORIO, P., GANDINI, P., REY, AR. and BOERSMA, PD. Los pingüinos de las costas Argentinas: estado poblacional y conservación. El Hornero, 2005, vol. 20, n. 1, p. 5-23.

SICK, H. Ornitologia brasileira. Rio de Janeiro: Nova Fronteira, 1997. 912 p.

SILVA, FASE and AZEVEDO, CAV. Principal components analysis in the software assistat-statistical attendance. In Proceedings of the World Congress on Computers in Agriculture, 2009. St. Joseph: American Society of Agricultural and Biological Engineers, 2009.

SILVA, FASE. and AZEVEDO, CAV. Versão do programa computacional Assistat para o sistema operacional Windows. Revista Brasileira de Produtos Agroindustriais, 2002, vol. 4, n. 1, p. 71-78. http://dx.doi. org/10.15871/1517-8595/rbpa.v4nlp71-78.

SILVA, FASE. The ASSISTAT Software: statistical assistance. In: Proceedings of the International Conference on Computers in Agriculture, 1996. Cancun: American Society of Agricultural Engineers, 1996. p. 294-298.

SILVA, FASE. and AZEVEDO, CAVA. New version of the assistatstatistical assistance software. In: Proceedings of the World Congress on Computers in Agriculture, 2006. St. Joseph: American Society of Agricultural and Biological Engineers, 2006. p. 393-396.

SILVINO, MJ. Aspectos morfométricos da glândula pineal em ratos e coelhos. São Paulo: Universidade de São Paulo, 1999. 70 p. [Tese de Doutorado em Anatomia dos Animais Domésticos e Silvestres].
SILVINO, MJ., MIGLINO, MA., DIDIO, LJA. and HERNANDESBLASQUEZ, FJ. The pineal gland in adult " golden cutia" (Dasyprocta aguti, Rodentia Vaviomorpha). Revista Chilena de Anatomia, 1995, vol. 13, n. 1, p. 17-23.

SINGH, NS. and DIXIT, AS. Morphology and ultrastructural studies of pineal organ of the tree sparrow (Passer montanus). Micron (Oxford, England), 2014, vol. 58, p. 9-14. http://dx.doi.org/10.1016/j. micron.2013.10.015.

SPIROFF, BEN. Embryonic and post-hatching development of the pineal body of the domesctic fowl. The American Journal of Anatomy, 1958, vol. 103, n. 3, p. 375-402. http://dx.doi.org/10.1002/ aja.1001030304. PMid:13649578.

STOKES, DL., BOERSMA, PD. and DAVIS, LS. Satellite Tracking of Magellanic Penguin Migration. The Condor, 1998, vol. 100, n. 2, p. 376-381. http://dx.doi.org/10.2307/1370280.

VANSTREELS, RET., ADORNES, AC., CANABARRO, PL., RUOPPOLO, V., AMAKU, M., SILVA-FILHO, RP. and CATÃODIAS, JL. Female-biased mortality of Magellanic Penguins (Spheniscus magellanicus) on the wintering grounds. Emu, 2013, Collingwood, vol. 113 , n. 2 , p. 128-134

VANSTREELS, RET., ADORNES, AC., RUOPPOLO, V., CANABARRO, PL., SILVA-FILHO, RP. and CATÃO-DIAS, JL. Gender determination from morphometrics in migrating Magellanic Penguins Spheniscus magellanicus. Marine Ornithology, 2011, vol. 39 , p. $215-220$.

VENZKE WG. Endrocrinologia geral. In GETTY, R. Anatomia dos animais domésticos. 5th ed. Rio de Janeiro: Guanabara Koogan, 1986. vol. 2, p. 49-150.

VOLLRATH, L. Mammaliam pinealocytes: ultrastrucutural aspects and innervation. In EVERED, D. and CLARK, S. Photoperiodism melatonin and the pineal. London: Pittman, 1985. p. 9-22.

VOOREN, CM. and BRUSQUE, LF. As aves do ambiente costeiro do Brasil: biodiversidade e conservação. Rio Grande: Fundação Universidade do Rio Grande, 1999, 57 p.

WEIGERT, SC., KLIPPEL, S., MADUREIRA, LSP., VOOREN, CM., PINHO, MP. and FERREIRA, CS. As águas da plataforma sul como ambiente físico. In VOOREN, CM. e KLIPPEL, S. (Org.). Ações para a conservação de tubarões e raias no sul do Brasil. Porto Alegre: Igaré, 2005. p. 23-33.

WILLIAMS, TD. and BOERSMA, PD. Magellanic penguin. In WILLIAMS, TD. (Org.). The penguins. Oxford: Oxford University Press, 1995. p. 249-258.
Received October 23, 2014 Accepted November 17, 2015 